\title{
Titanium Dioxide Derived Materials with Superwettability
}

\author{
Xianfeng Luo ${ }^{1,2} \mathbb{D}^{\text {, Zhongpeng Zhu }}{ }^{3}$, Ye Tian ${ }^{1,4, *}$, Jun You ${ }^{2}$ and Lei Jiang ${ }^{1,3,4, *}$ \\ 1 Key Laboratory of Bio-Inspired Materials and Interfacial Science, Technical Institute of Physics and Chemistry, \\ Chinese Academy of Sciences, Beijing 100190, China; xianfengluo65@gmail.com \\ 2 Key Laboratory of Green Chemical Engineering and Technology of Heilongjiang Province, \\ College of Materials Science and Engineering, Harbin University of Science and Technology, \\ Harbin 150040, China; youjun@hrbust.edu.cn \\ 3 Key Laboratory of Bio-Inspired Smart Interfacial Science and Technology of Ministry of Education, \\ School of Chemistry, Beihang University, Beijing 100191, China; zhuzp@buaa.edu.cn \\ 4 School of Future Technology, University of Chinese Academy of Sciences, Beijing 101407, China \\ * Correspondence: tianyely@iccas.ac.cn (Y.T.); jianglei@iccas.ac.cn (L.J.)
}

Citation: Luo, X.; Zhu, Z.; Tian, Y.; You, J.; Jiang, L. Titanium Dioxide Derived Materials with Superwettability. Catalysts 2021, 11, 425. https://doi.org/10.3390/ catal11040425

Academic Editors: Chiaki Terashima, Hideki Sakai, Ken-ichi Katsumata and Norihire Suzuki

Received: 10 February 2021

Accepted: 22 March 2021

Published: 26 March 2021

Publisher's Note: MDPI stays neutral with regard to jurisdictional claims in published maps and institutional affiliations.

Copyright: (C) 2021 by the authors Licensee MDPI, Basel, Switzerland. This article is an open access article distributed under the terms and conditions of the Creative Commons Attribution (CC BY) license (https:/ / creativecommons.org/licenses/by/ $4.0 /)$.

\begin{abstract}
Titanium dioxide $\left(\mathrm{TiO}_{2}\right)$ is widely used in various fields both in daily life and industry owing to its excellent photoelectric properties and its induced superwettability. Over the past several decades, various methods have been reported to improve the wettability of $\mathrm{TiO}_{2}$ and plenty of practical applications have been developed. $\mathrm{The} \mathrm{TiO}_{2}$-derived materials with different morphologies display a variety of functions including photocatalysis, self-cleaning, oil-water separation, etc. Herein, various functions and applications of $\mathrm{TiO}_{2}$ with superwettability are summarized and described in different sections. First, a brief introduction about the discovery of photoelectrodes made of $\mathrm{TiO}_{2}$ is revealed. The ultra-fast spreading behaviors on $\mathrm{TiO}_{2}$ are shown in the part of ultra-fast spreading with superwettability. The part of controllable wettability introduces the controllable wettability of $\mathrm{TiO}_{2}$-derived materials and their related applications. Recent developments of interfacial photocatalysis and photoelectrochemical reactions with $\mathrm{TiO}_{2}$ are presented in the part of interfacial photocatalysis and photoelectrochemical reactions. The part of nanochannels for ion rectification describes ion transportation in nanochannels based on $\mathrm{TiO}_{2}$-derived materials. In the final section, a brief conclusion and a future outlook based on the superwettability of $\mathrm{TiO}_{2}$ are shown.
\end{abstract}

Keywords: titanium dioxide; controllable wettability; ultra-fast spreading; photoelectrode; nanochannels

\section{Introduction}

$\mathrm{TiO}_{2}$ is widely used in practical applications and daily life due to its special properties [1], especially the applications of its photo-induced wettability. Many plants and animals in nature possess special wettability that can provide inspiration for research work, such as lotus leaves [2], fly eyes [3], gecko feet [4], the pitcher [5], etc. [6,7]. In 1964, Fowkes [8] provided a theory for calculating surface energy. He decomposed the surface tension into two forces: London dispersion force and polar force composed of dipole force, hydrogen bonds, and induced force. In 1969, Owens and Wendt [9] developed Fowkes theory, which considered that besides London dispersion force, there were polar effects including induced force, orientation force, and hydrogen bonds at the liquid-solid interface. In 1972, Fujishima and Honda [10] reported photolysis of water through an electrolytic cell that connects a $\mathrm{TiO}_{2}$ electrode and a platinum electrode. When the $\mathrm{TiO}_{2}$ electrode was irradiated by light, the current flow occurred and the oxygen was produced. The way oxygen is produced by oxidizing water is like the way it is produced by photosynthesis in nature. In 1997, Wang et al. [11] reported a property named "superamphiphilicity", which denotes that the static contact angles (CAs) of both water and oil are approaching $0^{\circ}$ on the surface of $\mathrm{TiO}_{2}$ under UV illumination. The mechanism can be explained by the formation of oxygen vacancies and the conversion of $\mathrm{Ti}^{4+}$ sites to $\mathrm{Ti}^{3+}$ sites due to UV light. These defects influence the affinity to chemisorbed water at the surrounding sites 
and, in turn, hydrophilic and hydrophobic nanodomains form on superamphiphilic $\mathrm{TiO}_{2}$ surfaces [12]. In addition, self-cleaning and anti-fogging characteristics are reported on $\mathrm{TiO}_{2}$ surfaces [11]. A growing number of researchers have paid attention to $\mathrm{TiO}_{2}$-derived materials with superwettability.

Generally, superwettability refers to superhydrophilic, superhydrophobic, superamphiphilic, and superamphiphobic surfaces; the mechanism of the superwettability property can be explained based on the surface structure of materials, surface molecules, and external influencing factors [13]. Surface wettability can be attributed to surface chemical composition and structure [14,15]. For $\mathrm{TiO}_{2}$, surface superwettability can be induced by photocatalysis, and with its excellent performance, $\mathrm{TiO}_{2}$ is increasingly being used in energy [16,17], textile [18,19], and catalysis [20], etc. Recently, important breakthroughs were made in the technology and basic research of $\mathrm{TiO}_{2}$, which included design of structures, modification on substrate, and multidirectional applications [21-31]. Some of the typical applications of $\mathrm{TiO}_{2}$ are shown in Figure 1. In this review, a number of recent works are summarized from different fields including ultra-fast spreading, controllable wettability, interfacial photocatalysis, and nanochannels.

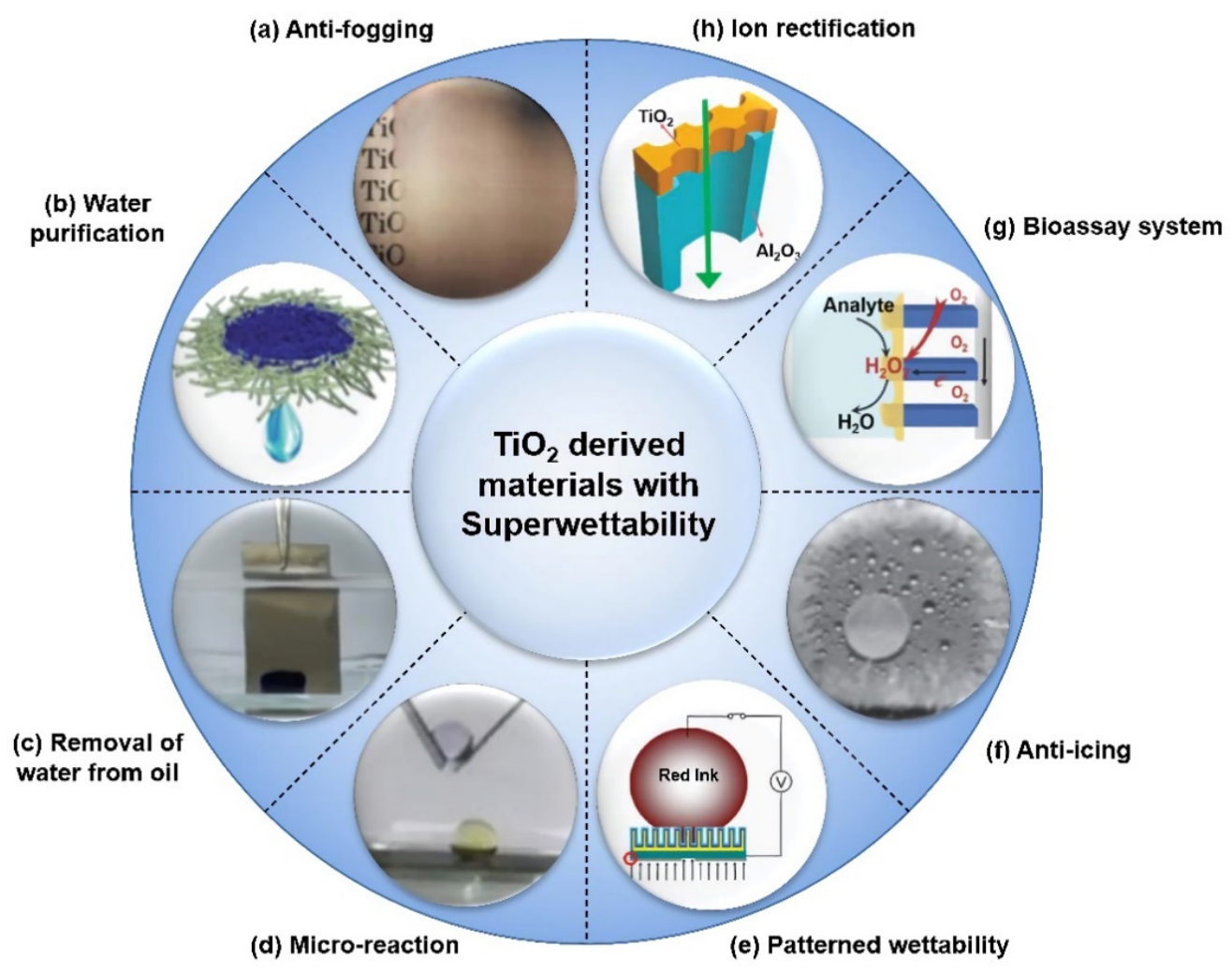

Figure 1. Typical applications of $\mathrm{TiO}_{2}$ based on photo-induced superwettability. (a) Glass substrate coated with nano- $\mathrm{TiO}_{2}$ shows anti-fogging properties. Reprint from [11]. Copyright (1997), with permission from Nature Publishing Group, Basingstoke, UK. (b) Water can be purified through a $\mathrm{TiO}_{2}$ nanomembrane by adsorption of organic pollutants. Reprint from [32]. Copyright (2013), with permission from The Royal Society of Chemistry, London, UK. (c) Removal of water from oil with UV-illumination on a superhydrophilic $\mathrm{TiO}_{2}$ nanotube array $\left(\mathrm{TiO}_{2}-\mathrm{NTA}\right)$ surface. Reprint from [33]. Copyright (2018), with permission from American Chemical Society, Washington, DC, USA. (d) Under-oil microreaction on the fabricated superhydrophilic $\mathrm{TiO}_{2}-\mathrm{NTA}$ surface. Reprint from [33]. Copyright (2018), with permission from American Chemical Society, Washington, DC, USA. (e) Patterned wettability used for printing on the $\mathrm{TiO}_{2}$ surface via the photoelectric cooperative effect. Reprint from [34]. Copyright (2009), with permission from WILEY-VCH, Weinheim, Germany. (f) Antiicing property is shown on a $1 \mathrm{H}, 1 \mathrm{H}, 2 \mathrm{H}, 2 \mathrm{H}$-perfluorooctyltriethoxysilane-modified superhydrophobic $\mathrm{TiO}_{2}$-NTA surface. Reprint from [35]. Copyright (2014), with permission from WILEY-VCH, Weinheim, 
Germany. (g) The solid-liquid-air triphase bio-photoelectrode was fabricated by single-crystalline $\mathrm{TiO}_{2}$ nanowire arrays (NWs) for the bioassay system. Reprint from [36]. Copyright (2018), with permission from WILEY-VCH, Weinheim, Germany. (h) $\mathrm{TiO}_{2}$ nanochannels can be used to fabricate artificial ion channels. Reprint from [37]. Copyright (2014), with permission from WILEY-VCH, Weinheim, Germany.

\section{Ultra-Fast Spreading with Superwettability}

Ultra-fast spreading has long been a research topic, and $\mathrm{TiO}_{2}$-based materials are one of the widely used superspreading materials due to their unique photocatalysis properties $[7,38,39]$. Ultra-fast spreading is a wetting phenomenon indicating liquid permeates and diffuses into complex surface structures containing pores, taking advantage of the capillary effect [40]. Liquid shows ultra-fast spreading behaviors on $\mathrm{TiO}_{2}$-derived materials because of the aforementioned photo-induced superwettability and the structure of the surface, which can be regulated on demand [3,41-43].

The formation of nano-sized structures is helpful to the ultra-fast spreading behavior of droplets. Li et al. [44] reported nanostructured metal nitrides with the desirable property of superwettability. Compared to traditional TiN nanoparticle structures, the connected nanofibers and nanotubes structures have a larger surface-to-volume ratio, larger specific surface area, better mechanical stability, and independent transmission channels. A hierarchical amorphous $\mathrm{TiO}_{2}$ nanoarray reported by Li et al. [45] showed superamphiphilicity without UV-illumination. This is due to the preparation method called pulsed laser deposition, which is more cost-effective than the traditional process. Meanwhile, many $\mathrm{TiO}_{2}$ surfaces have special structures that show the property of superwettability. Zorba et al. [46] reported a self-similar porous $\mathrm{TiO}_{2}$ surface with superhydrophilic properties without UVirradiation. The water CAs release to less than $5^{\circ}$ quickly, in $160 \mathrm{~ms}$. With the introduction of $\mathrm{TiO}_{2}$ onto the glass substrate, the coating showed obvious anti-fogging performance. Denison et al. [47] reported ultra-fast spreading behavior of water droplets on a transparent mesoporous superhydrophilic $\mathrm{TiO}_{2}$ film prepared by reverse micelle, sol-gel, and spin coating technology. The photo-induced stick-slip behavior on mesoporous $\mathrm{TiO}_{2}$ can be observed by investigating the spreading of water droplets on the semiconductor surface irradiated by ultraviolet light. By means of electrospinning, Ganesh et al. [48] reported that a rice-shaped $\mathrm{TiO}_{2}$ nanostructure showed superhydrophilicity. The superhydrophilicity of $\mathrm{TiO}_{2}$ coatings depends on their thickness. Electrospinning $\mathrm{TiO}_{2}$ shows better photocatalytic performance than commercial Degussa P25. Funakoshi et al. [49] prepared a superhydrophilic anatase $\mathrm{TiO}_{2}$ film by a titanium alkoxide hydrolysis operation. The water CAs and the transmittance of visible light to its substrate vary with the duration of tetraethyl orthotitanate (TEOT) hydrolysis operation. In the hydrolysis process of TEOT, the water CAs on the film shows about $35^{\circ}$, and when the process is longer than $60 \mathrm{~min}$, the CAs drops below $1^{\circ}$. With the prolongation of the hydrolysis time of TEOT, the transmittance of light through its substrate is low.

In addition to the formation of nano-sized structures, fabrication of microstructures also influences surface superwettability. Kobayashi et al. [50] observed ultra-fast spreading on a $\mathrm{TiO}_{2}$ micropillar arrays with overhanging roofs. When the geometrical angle between the overhanging roof and the vertical micropillar shaft decreased from $51^{\circ}$ to $9^{\circ}$, the wettability transition time when storing in dark and under UV illumination decreased from $180 \mathrm{~min}$ to $6 \mathrm{~min}$.

In contrast to nanostructures and microstructures, the micro-nano composite structure can make the surface ultra-fast spreading more obvious. Joung et al. [51] fabricated a superhydrophilic micro-nano composite porous $\mathrm{TiO}_{2}$ structure by electrophoretic deposition and breakdown anodization. The thin film prepared by the electrophoretic deposition method shows a nanostructure and a basis for producing a superhydrophilic porous structure by the breakdown anodization method. On the basis of the superwettability property of $\mathrm{TiO}_{2}$, the spreading ability of $\mathrm{TiO}_{2}$ can be greatly enhanced by adjusting the structure, such as a to a mesh structure. Wang et al. [52] reported a superhydrophilic $\mathrm{TiO}_{2}$ fibrous 
mesh with an ultra-fast spreading property (Figure 2a). The mesh is made by tetrabutyl titanate and poly (vinyl pyrrolidone) composed of polycrystalline anatase $\mathrm{TiO}_{2}$, and it has three-dimensional micropores surrounded by nanofibers, and the nanochannel structure of a single fiber promotes the superhydrophilicity of water (Figure 2b). The water droplet spreads more quickly on the surface of a fiber mesh composed of the superhydrophilic fibers (Figure 2c). The capillary effect in three dimensions induces the wetting of water in the vertical direction (Figure 2d). The final wetting state shows that CAs is $0^{\circ}$. Similar to $\mathrm{TiO}_{2}$ fiber mesh, Wen et al. [32] reported superhydrophilic $\mathrm{SiO}_{2}-\mathrm{TiO}_{2}$ porous nanofibrous membranes through electrospinning and calcination. This material shows the characteristics of ultra-fast water wettability (Figure 2f) and the graded porous structure of the nanofiber membrane is beneficial for improving adsorption capacity and permeability. The membrane was useful for water purification (Figure $2 \mathrm{~g}$ ). Based on the micro-nano composite structure, the fabrication of the internal structure of the fiber depends on electrospray technology and helps to form a superhydrophilic surface. In 2008, Chen et al. [53] proposed a simple fluid electrospray technology to produce multi-component microcapsules. A novel multicompartment accomplished one-step multi-component encapsulation. This simple and effective composite fluid electrospray technique is crucial for separating and encapsulating active components. In 2010, Chen et al. [54] proposed a multifluidic coaxial electrospinning method for nanowire-in-microtube structured preparation. Compared with the multifluidic electrospinning method, the new one method adds an extra middle fluid between the polyacrylonitrile core and the polystyrene shell fibers. The advantage is the introduction of the additional intermediate fluid is that it can effectively reduce the interaction between the other two fluids. Further, in 2011, Chen et al. [55] reported a hierarchically porous inorganic nanofiber structure using microemulsion electrospinning. With the increase of precursor concentration, the diameter of nanopores increases. Meanwhile, the internal structure of the fiber can be controlled by changing the composition of micro-emulsion and the conditions of cations.
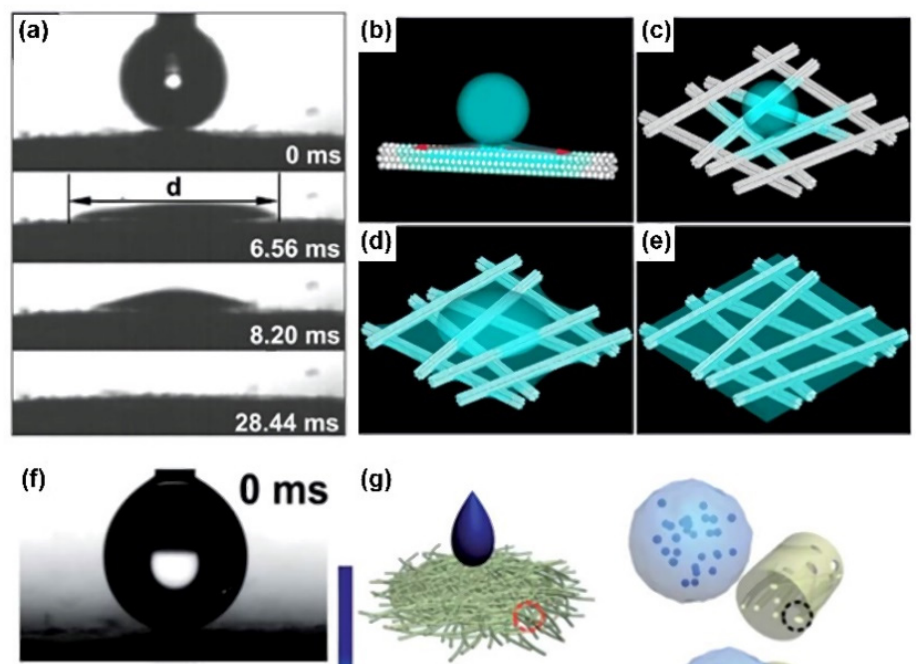

(g)
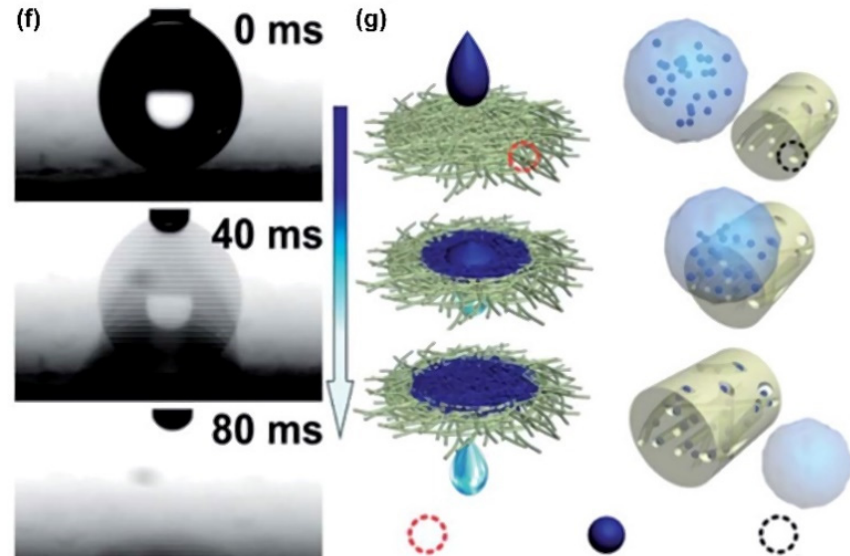

Interfiber pore MB molecule Intrafiber pore

Figure 2. Ultra-fast spreading behaviors on the $\mathrm{TiO}_{2}$ surface for water purification. (a) A water droplet 
spreads on a $\mathrm{TiO}_{2}$ superhydrophilic mesh in $28.44 \mathrm{~ms}$. (b)The one-dimensional nanochannels of a single nanofiber, which generate a capillary effect to pull water along with the precursor water film. (c) The capillary effect of several nanofibers promotes the diffusion of water on the top surface of the fiber mesh. (d) The capillary effect caused by 3D micropores further promotes the diffusion of water droplets after inducing the invasion of water in the vertical direction. (e) The final state of the mesh shows contact angles (CAs) around $0^{\circ}$. Reprint from [52]. Copyright (2009), with permission from Elsevier, Amsterdam, The Netherlands. (f) A water droplet spreads on a flexible $\mathrm{SiO}_{2}-\mathrm{TiO}_{2}$ composite porous nanomembrane in $80 \mathrm{~ms}$. (g) The methylene blue solution spreads rapidly on the $\mathrm{SiO}_{2}-\mathrm{TiO}_{2}$ composite porous nanofibrous membrane and permeates through the interspace between nanofibers in the membrane. Meanwhile, methylene blue molecules are captured by intra-fiber pores, and then a water droplet is obtained. Reprint from [32]. Copyright (2013), with permission from The Royal Society of Chemistry, London, UK.

\section{Controllable Wettability}

In addition to superspreading properties, controllable superwettability, which denotes the effective conversion between superhydrophilicity and superhydrophobicity, is widely studied and used in daily life because of its applications in smart devices such as printing, microfluidics, and water collection [56-60].

UV-induced superwettability was first reported by Fujishima et al. [11]. With UV-light illuminated on $\mathrm{TiO}_{2}$ film, the water $\mathrm{CA}$ is $0^{\circ}$. After storing the film in the dark, a high $\mathrm{CA}$ of about $72^{\circ}$ of the film is recovered. After that, much related research was further carried out. Kang et al. [33] reported on the under-oil switchable wettability of $\mathrm{TiO}_{2}$ nanotube arrays $\left(\mathrm{TiO}_{2}-\mathrm{NTAs}\right)$. Comparison between $\mathrm{TiO}_{2}-\mathrm{NTAs}$ and $\mathrm{TiO}_{2}$-films showed that they have the same superhydrophilicity in air but different wettability under-oil. With UV irradiation, $\mathrm{TiO}_{2}$-NTAs reveal CAs of about $0^{\circ}$ under oil. After heating at $150{ }^{\circ} \mathrm{C}$ in air, the superhydrophobicity appears again. Zeng et al. [61] reported a new heterostructure with the $\mathrm{TiO}_{2}$-NTAs composited with $\mathrm{Ni}(\mathrm{OH})_{2}$, which shows a photo-induced color change by oxidative energy storage. The oxidative energy is generated by $\mathrm{TiO}_{2}$ nanotubular arrays under UV light, and the oxidative energy can be reserved in the $\mathrm{Ni}(\mathrm{OH})_{2}$ layer. The color change phenomenon can be shown with reducing agents' bleaching such as with alcohol, hydrogen peroxide, and ketone solutions. This storage-releasing oxidative energy-induced color change switch shows good reversibility. Gao et al. [62] reported a switchable superwettability membrane called a biomimetic $\mathrm{TiO}_{2}$-titanium mesh. A controllable underwater superwettability was shown by UV-illumination and heating. In terms of nanotube array structure, Chagas et al. [63] reported fabrication of $\mathrm{TiO}_{2}$ nanoparticle@trimethoxypropyl silane on a polypropylene substrate. The water CAs showed a change between superhydrophobic and superhydrophilic with UV light and heating. Additionally, UV light can increase the adhesion of the $\mathrm{TiO}_{2}$ nanoparticle@trimethoxypropyl silane coating. Caputo et al. [64] reported controllable wettability on a colloidal $\mathrm{TiO}_{2}$ nanocrystal film under UV irradiation. A low water CA was shown after UV illumination. Meanwhile, a vacuum environment can accelerate the change of wettability. Wang et al. [65] reported a nanotube-structured $\mathrm{TiO}_{2}$ film with switchable water adhesion. The hydrophilic region is generated by ultraviolet irradiation, and the alternating hydrophilic/superhydrophobic alignment is realized by using a mask. This phenomenon was applied to potential in-water drop manipulation. Feng et al. [66] prepared a $\mathrm{TiO}_{2}$ nanorod film with a special micro-nano composite structure on glass substrate, which shows superhydrophobic behavior. After UV irradiation, water CAs of the sample change from superhydrophobic to superhydrophilic. The $\mathrm{TiO}_{2}$ nanorod is shown in Figure 3a,b. As a photosensitive material, with UV illumination, the photogenerated hole combines with lattice oxygen to form surface oxygen vacancies, then, the film revealed water $\mathrm{CAs}$ of about $0^{\circ}$. After storage in the dark, finally, the surface wettability converted from superhydrophilic to superhydrophobic again (Figure 3c). Repeated reversible superhydrophilic-superhydrophobic transition is shown in Figure 3d. 

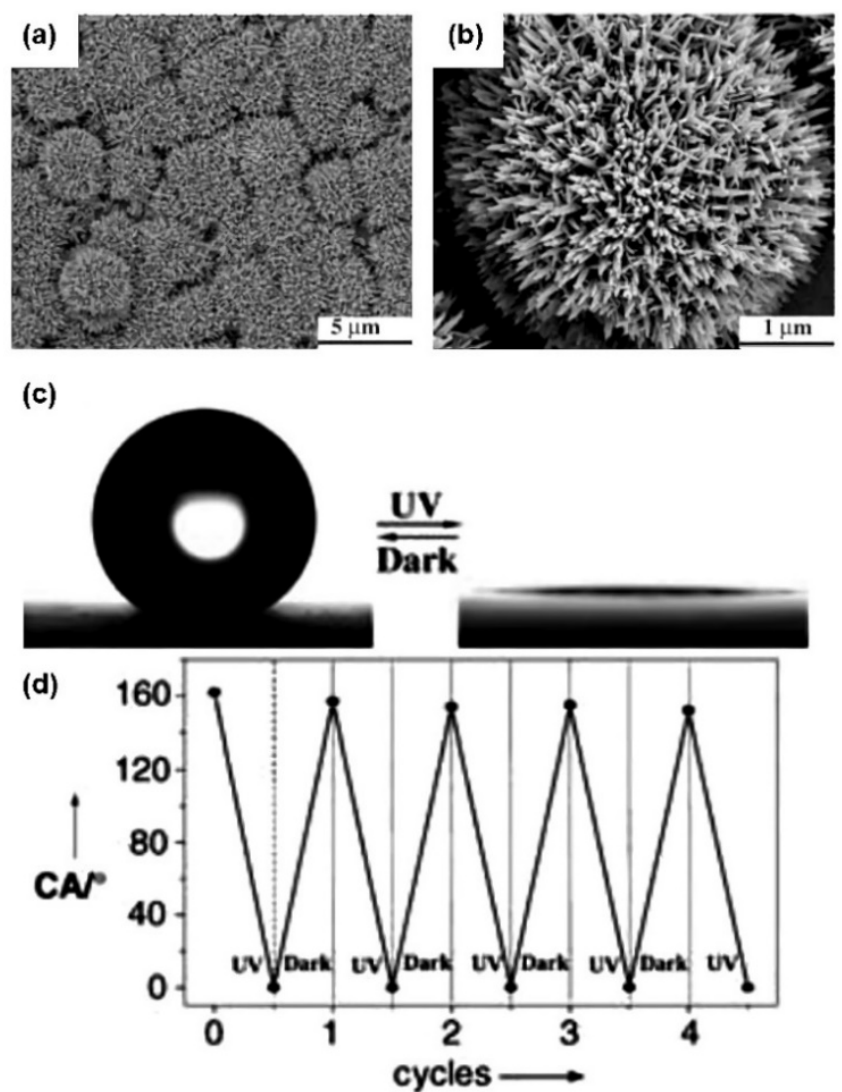

Figure 3. Switchable wettability of a $\mathrm{TiO}_{2}$ nanorod under UV light and storage in dark. (a) Lowmagnification FE-SEM image of a $\mathrm{TiO}_{2}$ nanorod film deposited on a glass wafer; (b) Morphology of a single papilla at high magnification; (c) Photographs of a water droplet changing during UVillumination and storage in dark; (d) Reversible superhydrophilic-superhydrophobic transition of the $\mathrm{TiO}_{2}$ films by UV and storage in dark. Reprint from [66]. Copyright (2005), with permission from WILEY-VCH, Weinheim, Germany.

In addition to ultraviolet irradiation, other external stimuli can also be applied to achieve controllable wettability of $\mathrm{TiO}_{2}$. Lian et al. [67] reported a controllable wettability on $\mathrm{TiO}_{2}$ rough surfaces with ethanol immersion and dark storage. The experiment phenomenon shows the changing CAs via the change of hydroxyl. A special nanostructure was reported by Lai et al. [68] who designed three controllable adhesion and superhydrophobic nanostructures, which include nanopores, nanotubes, and a nanovesuvianite array. The adhesion of water can be controlled by changing the diameter or length of nanotubes. This design guides the new functional nanomaterials with custom-tailored surface hydrophobicity and adhesion. Hu et al. [35] reported superhydrophobic $\mathrm{TiO}_{2}-\mathrm{NTAs}$ with controllable water adhesion. These $\mathrm{TiO}_{2}-\mathrm{NTAs}$ were modified by $1 \mathrm{H}, 1 \mathrm{H}, 2 \mathrm{H}, 2 \mathrm{H}-$ perflfluorooctyl-triethoxysilane (PTES). The result shows that when a nanotube's diameter or length increased, the adhesion of water was reduced. Following this feature, a water droplet can be transferred from having low adhesive superhydrophobic $\mathrm{TiO}_{2}-\mathrm{NTAs}$ to high adhesive superhydrophobic $\mathrm{TiO}_{2}$-NTAs, and then to a smooth Ti film. The high adhesive $\mathrm{TiO}_{2}$-NTAs were used as "mechanical hands", and an anti-icing property was revealed on the low adhesion $\mathrm{TiO}_{2}$-NTA surface. Moreover, a switch of the electric field can control the dynamic wettability. Li et al. [69] reported a strategy for achieving controllable liquid manipulation and transportation on a micro-nano structured elastomer film via an electric field. Wettability is controlled according to the stretching/releasing of the elastomer $\mathrm{TiO}_{2}$ surface. After coating with carbon grease and applying an electric field, when the voltage was applied, the shortening of the distance of the micro-nano composite structure clusters could be triggered. Liu et al. [70] reported a $\mathrm{TiO}_{2} /$ reduced 
graphene oxide composite aerogel that was used for selectively degrading pollutants in water and depended on its photocatalysis properties. $\mathrm{TiO}_{2}$ nanostructures have been grown on three-dimensional reduced graphene oxide porous structures and play an important role. Pan et al. [71] reported a $\mathrm{TiO}_{2}$ nanoparticle (NP) coating modified with $1 \mathrm{H}, 1 \mathrm{H}, 2 \mathrm{H}, 2 \mathrm{H}-$ perfluorooctyl(trimethoxy)silane. The CAs could rapidly change from $165^{\circ}$ to $0^{\circ}$ in $10 \mathrm{~min}$ after heating. Meanwhile, the membrane can be used to separate oil and water.

Controllable wettability can be applied to oil-water separation. Shi et al. [72] fabricated a $\mathrm{TiO}_{2} @$ copper wire mesh. The $\mathrm{TiO}_{2} @$ @opper wire mesh covered with a $\mathrm{TiO}_{2}$ micro-nano composite structure has a transforming wettability of less than $30 \mathrm{~min}$ in addition to its property of switchable wettability applied for oil-water separation. Yan et al. [73] designed a carbon nanotubes $/ \mathrm{TiO}_{2}$ composite membrane, which was used to separate oil-water systems. The membrane exhibited high separation efficiency in oil-water separation. With the corrosive test and after several cycles, the material also showed a stable separation effect. Ren et al. [74] reported a superhydrophobic $\mathrm{TiO}_{2} @ \mathrm{CA} / \mathrm{AS}$ coating that was fabricated with chitosan (CS) and stearic acid (SA). The wettability can be controlled with ammonic and heat treatment and is used for separating oil and water.

Moreover, patterned printing based on controllable wettability has also become attractive. Tian et al. [34] reported a superhydrophobic nanorod array surface whose patterned wettability transition could be controlled by the photoelectric cooperative. Under the condition of only applying voltage, the wettability of the nanorod surface cannot be regulated. However, under a certain voltage, by controlling illumination, a controllable wettability interface with photoelectric cooperation can be formed (Figure $4 a, b$ ). With this property, a desired pattern " $\mathrm{H}$ " is obtained (Figure 4c). Guo et al. [75] reported an approach for patterned liquid permeation with a $\mathrm{TiO}_{2}$-NTAs coated Ti mesh. The wettability of this coated material can be controlled by the photoelectric response. The mechanism can be explained as follows. At first, the surface of the superhydrophobic Ti mesh with $\mathrm{TiO}_{2}-\mathrm{NTAs}$ becomes hydrophilic by introducing appropriate voltage and light. However, if the voltage is too high or too low, the hydrophilic phenomenon of photoelectric synergy cannot be obtained. In the same year, Guo et al. [76] reported a $\mathrm{ZnO}$ mesh surface with the micro-nano composite structure for liquid patterned printing. By adding voltage and illumination, a great difference can be created between patterned and un-patterned areas due to the micro-nano composite structure of the $\mathrm{ZnO}$ mesh. Patterned liquid printing is realized in this way. With different mechanisms on patterned printing, Zheng et al. [57] reported a $\mathrm{TiO}_{2}-\mathrm{SiO}_{2}$ composite coating used for electrostatic patterning. Temporary conductivity of the insulation surface was realized by electrostatic powder spraying. The water droplets sprayed on the superhydrophilic surface can diffuse rapidly and spread into a water film, and the first pass transfer efficiency is promoted to more than $80 \%$. After spraying the powder particles on the water film and heating it, an epoxy-polyester film on a porous composite coating was accomplished (Figure $4 \mathrm{~d}$,e). Surface patterning was completed by electrostatic attraction of negative charge of epoxy polyester powder and positive charge of water (Figure 4f,g). The micro-grade lines with different sizes are shown in Figure $4 \mathrm{~h}$. 
(a)

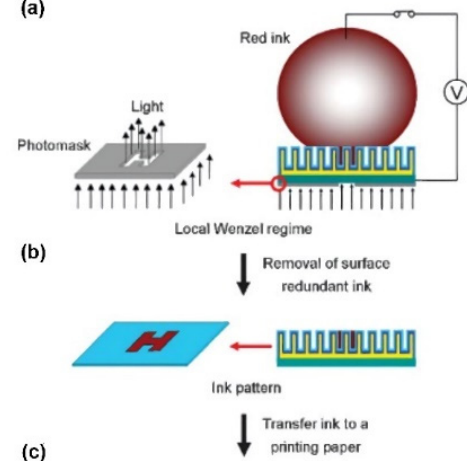

(c)



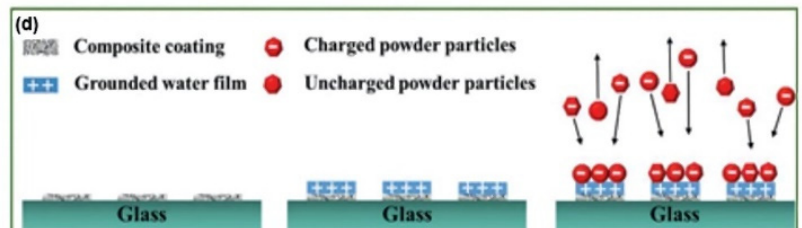
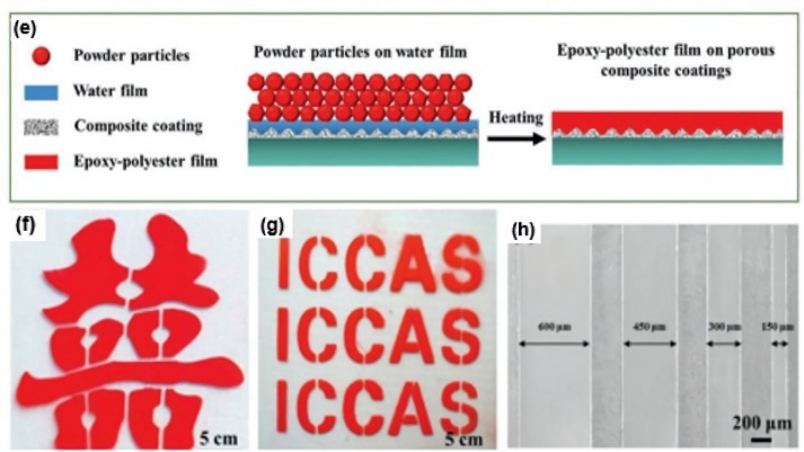

Figure 4. Liquid-patterned printing by $\mathrm{TiO}_{2}$ and its superwettability. (a) Red ink was printed on the composite $\mathrm{TiO}_{2}$ nanorod-array surface with illumination through the photomask. (b) After the illumination and voltage were turned off, an ink-patterned " $\mathrm{H}$ " was shown with the removal of the ink. (c) When the pattern is transferred onto the paper, the desired image " $\mathrm{H}$ " is obtained. Reprint from [34]. Copyright (2009), with permission from WILEY-VCH, Weinheim, Germany. (d) Process of the electrostatic attraction-induced patterning on the glass by spraying droplets on the glass patterned with a superhydrophilic nanoparticle (NP) coating. Electrostatic powder was adsorbed on the water film. (e) After heating for $20 \mathrm{~min}$, a patterned film formed on the glass. (f) The pattern of the "Red Double Happiness". (g) The pattern of "ICCAS". (h) SEM image shows the patterned glass with different sizes of micro-grade lines. Reprint from [57]. Copyright (2016), with permission from WILEY-VCH, Weinheim, Germany.

\section{Interfacial Photocatalysis and Photoelectrochemical Reactions}

Due to the photogenerated electron effect of $\mathrm{TiO}_{2}$, more and more practical applications are emerging in interfacial photocatalysis and photoelectrochemical (PEC) reactions. For interfacial photocatalysis, a photodegradation system composed of $\mathrm{TiO}_{2}$ has an advantage in environmental protection and renewable energy, which has attracted the attention of researchers $[77,78]$.

Niu et al. [79] reported a $\mathrm{TiO}_{2}$ / polypropylene composite membrane on which the flowing organic dyes can be completely photodegraded under the irradiation of ultraviolet rays. During the process, the aqueous solution selectively wetted the hydrophilic porous nano- $\mathrm{TiO}_{2}$ and skipped the superhydrophobic substrate, meaning most of the dye molecules were in direct contact with the active site of $\mathrm{TiO}_{2}$ for complete degradation. The bleaching effect of congo red dye was better with the increase of $\mathrm{TiO}_{2}$ NP. Tao et al. [80] reported a nano-porous anatase $\mathrm{TiO}_{2}$ film deposited with $\mathrm{Cu}_{\mathrm{x}} \mathrm{O}$ quantum dots through a continuous ionic layer adsorption reaction. The microstructure, morphology, and loading capacity of $\mathrm{Cu}_{x} \mathrm{O}$ quantum dots on $\mathrm{TiO}_{2}$ thin films were controlled by changing the cycle times of successive ionic layer adsorption reactions. This kind of electrode showed better photoelectric performance and might be applied to solar energy conversion and water degradation. These applications often rely on rapid wetting where the superwettability of $\mathrm{TiO}_{2}$ can be promoted.

For PEC reactions, $\mathrm{TiO}_{2}$ can participate in the formation of bioelectrodes. Recent works have reported on bioelectrodes and triphase reactions. The solid-liquid-gas triphase reaction, which is based on the bioelectrode, exhibited higher detection sensitivity and a larger detection range of the sensor than those of the normal solid-liquid diphase reaction. It is precisely because of the superwettability of $\mathrm{TiO}_{2}$ that the triphase reaction system can be formed. These works enlighten our further understanding and research in this field [81-83]. 
Photoelectrochemical reactions applied to PEC biological detection systems have been studied. Wang et al. [36] reported a PEC biological detection system. The SEM image showed that $\mathrm{TiO}_{2}$ nanowires (NWs) were fabricated on transparent fluorine-doped tin oxide-coated glass (Figure 5a) and their surfaces were completely covered by a graphene oxide/chitosan composite layer (Figure $5 b$ ). This system was composed of a photoanode composed of single crystal semiconductor NWs and a biocathode stationary oxidase on the surface of the superhydrophobic NWs (Figure $5 \mathrm{c}$ ). $\mathrm{H}_{2} \mathrm{O}_{2}$ played a crucial role in the reductase reaction occurring at the three-phase contact interface (Figure $5 \mathrm{~d}, \mathrm{e}$ ). This kind of PEC bioassay system had the advantage of higher detection sensitivity and range. Compared with the diphase PEC system in a PBS solution at different oxygen concentrations, photocurrents measured with different $\mathrm{H}_{2} \mathrm{O}_{2}$ concentrations showed that the triphase bioassay system revealed stable electrolyte oxygen levels, which means the fluctuation was small (Figure $5 \mathrm{f}$ ). The strong photocurrent response appeared at $0 \mathrm{~V}$, which means that the three-phase measurement process can be carried out without external bias (Figure 5g). With a similar application, Chen et al. [84] designed a triphase bio-photoelectrode that was built with superhydrophobic $\mathrm{TiO}_{2} \mathrm{NW}$ surfaces and oxidase was fixed to the nanowire array. The bio-photoelectrode can obviously enhance the oxidase kinetics, efficient transfer, and collection of photogenerated charge. The three-phase bio-photochemical detection system formed by the electrode promoted beneficial effects in medical treatment and clinical diagnosis, such as blood glucose, lactic acid, and cholesterol detection. In terms of modified materials, Zhang et al. [85] reported a method to control the PEC water-splitting performance on the $\mathrm{TiO}_{2}-\mathrm{NTA}$ surface. The result showed water CAs of about $134^{\circ}$, and octadecyltrimethoxysilane (OTS)-modified $\mathrm{TiO}_{2}$ nanotubes revealed better PEC properties. This was because of the suppression of the recombination of photogenerated electrons and holes and the improvement of the injection efficiency of photogenerated holes. However, its excessive thickness will affect the light absorption and inhibit the PEC properties.

Photocatalysis and PEC reactions can be applied in biomimetic materials and the osseointegration field. Rafieerad et al. [86] reported mixed oxide nanotubes (titania-niobiaalumina) that were prepared on an alloy, called Ti6Al7Nb implants, by physical vapor deposition (PVD) magnetron sputtering and the electrochemical method. First, under the optimized coating conditions, a thin film of niobium $(\mathrm{Nb})$ with good adhesion was sputtered by PVD, and then nanotube arrays were grown on the surface of $\mathrm{Nb} / \mathrm{Ti} 6 \mathrm{Al} \mathrm{N \textrm {Nb }}$ implants after anodizing and heat treatment. Last, the prepared graphene oxide (GO) nanosheets were loaded on the anode nanotubes to enhance the ternary ceramic membrane. Without GO, the water CA of mixed oxide nanotubes is $34.2^{\circ}$, which drops sharply to $23.6^{\circ}$ after GO loading. The results showed that compared with mixed oxide nanotubes, the hybrid composite of NTAs and GO provided a better connection between implant and bone. 

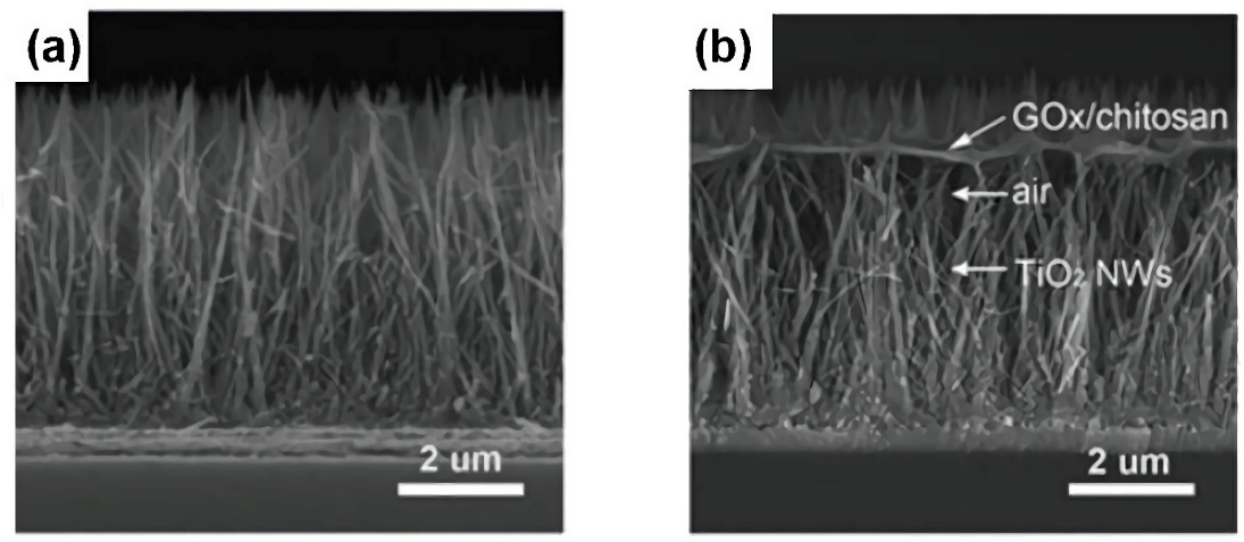

\section{(c)

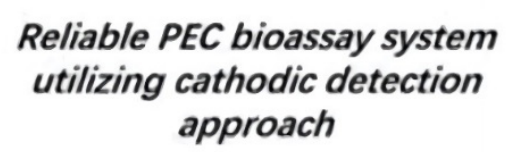


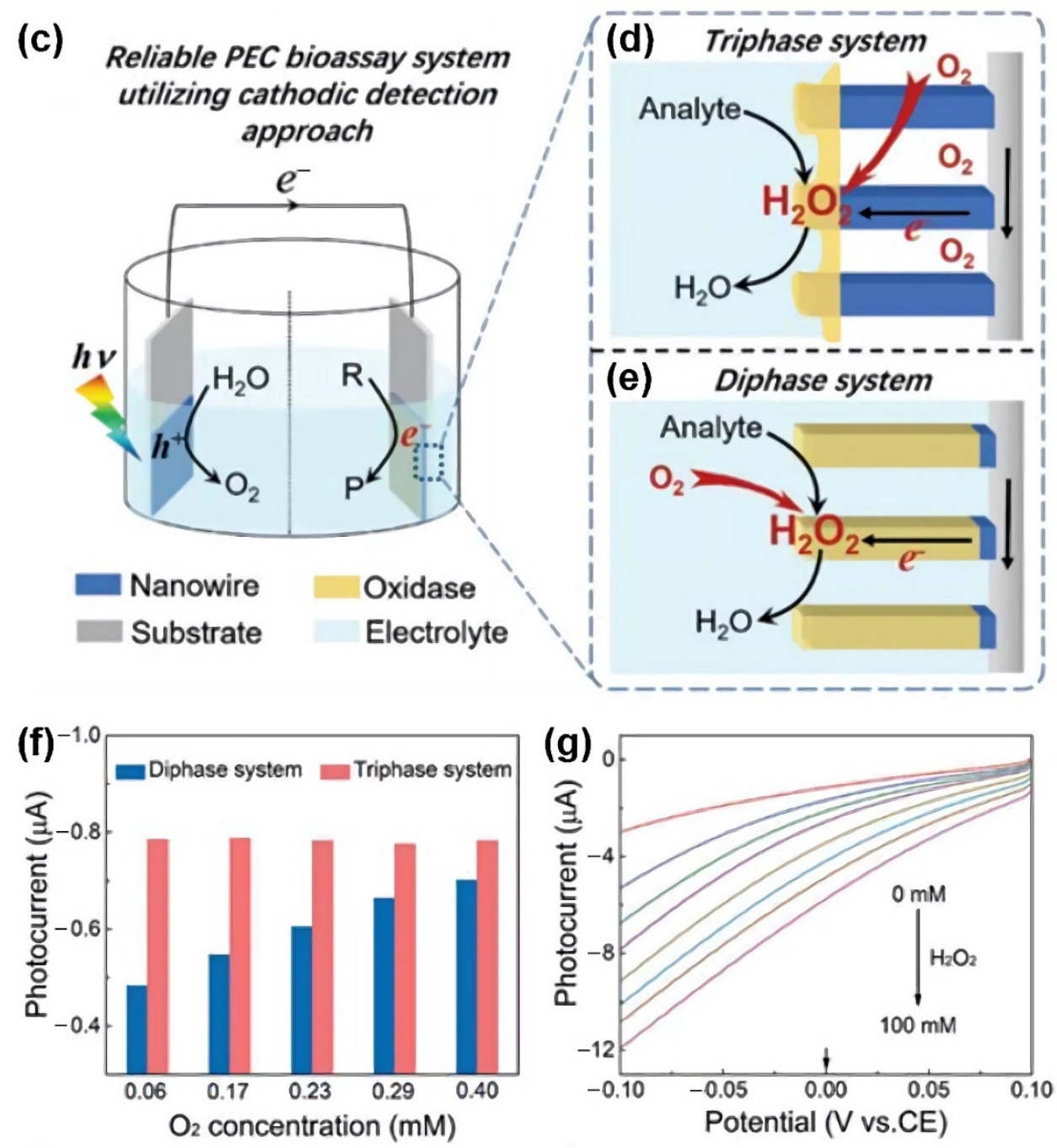

Figure 5. Schematic illustration of the morphology and composition of a photoelectrochemical (PEC) bioassay system and the advantages of the triphase system. (a) FE-SEM image of $\mathrm{TiO}_{2} \mathrm{NWs}$ fabricated on transparent the fluorine-doped tin oxide-coated glass substrate. (b) SEM image of the $\mathrm{TiO}_{2}$ NWs surface that is covered by a graphene oxide (GO)/chitosan composite layer. (c) Schematic image of the reliable PEC bioassay system. (d) Enlarged image of the triphase bio-cathode reaction zone. (e) Enlarged image of the diphase bio-cathode reaction zone. (f) Triphase PEC system shows higher photocurrents than those of the diphase PEC system. (g) Linear sweep voltammograms of the PEC system while measuring $\mathrm{H}_{2} \mathrm{O}_{2}$. Reprint from [36]. Copyright (2018), with permission from WILEY-VCH, Weinheim, Germany. 


\section{Nanochannels for Ion Rectification}

In addition to controlling the wetting behavior of water molecules with superwettability, $\mathrm{TiO}_{2}$ can also regulate the transport of ions in nanochannels. Size effect and surface charges are critical factors influencing the property of ion transport when nanochannels are constructed. Various significant properties can be found on $\mathrm{TiO}_{2}$-derived materials [87]. Inspired by biological ion channels, artificial nanochannels were prepared [88]. Plenty of research has been devoted to exploring the fundamental mechanism of nanochannels in recent years [89-92]. For bio-inspired ionic nano-channels, the importance of nano-scale ion transport based on $\mathrm{TiO}_{2}$-derived materials will be further enlarged in future biology and medicine [93-97].

The application of heterogeneous nanochannels for ion rectification was confirmed based on $\mathrm{TiO}_{2}$. Zhang et al. [98] fabricated $\mathrm{TiO}_{2}-\mathrm{NTAs}$ that benefitted ion channel transport. The artificial $\mathrm{TiO}_{2}-\mathrm{NTAs}$ with asymmetric structures can be used as ion channels regulated by UV light. UV light induced superwettability and inhibited ion transmission under positive voltage, while it promoted ion transmission under negative voltage. Liu et al. [99] reported $\mathrm{TiO}_{2}$ microspheres with mesoporous channels that were grown in situ at the tips of glass microtubes by confined space evaporation. The $\mathrm{TiO}_{2}$ micro-plug with asymmetric mesoporous channel showed strong ion current rectification abilities even in a saturated $\mathrm{KCl}$ solution.

With the modification of $\mathrm{TiO}_{2}$, Zhang et al. [37] reported a heterogeneous nanochannel composed of alumina and anatase type $\mathrm{TiO}_{2}$ with OTS molecules (Figure 6a-e). The material under UV light showed the characteristics of ion gating and ion rectification (Figure 6f,g). This can be explained by UV light-induced asymmetric distribution of negative surface charges, which form modified organic molecules on the surface of $\mathrm{TiO}_{2}$. The artificial $\mathrm{TiO}_{2}$ nanocomposites with asymmetric structures can be used as ion channels regulated by UV light, which affects not only surface wettability, controlling solution transmittance, but also decomposition of modified organic molecules on $\mathrm{TiO}_{2}$. To be specific, $\mathrm{TiO}_{2}$ can transform into a superhydrophilic state under UV irradiation. Meanwhile, UV irradiation induced the occurrence of hole-electron pairs in $\mathrm{TiO}_{2}$ and thus an oxidation of the organic molecules on surface, similarly to OTS. Decomposed organic anions form an electric field, which inhibist ion transmission under positive voltage (Figure 6h-k) [100]. It can be used in sensors and separation technologies. Hu et al. [101] described OTS modified $\mathrm{TiO}_{2}-\mathrm{NTAs}$ used for ion rectification. OTS was decomposed by UV illumination and carboxyl was introduced to the tip of the nanochannels. The water CAs of the tip side of the material proved this point. This artificial large-size nanochannel can be used for nano-fluidic diodes, sensors, and separations. The experiment revealed the intensity and direction of ion current rectification could be adjusted by $\mathrm{pH}$ or through the modification of citric acid. On the basis of the heterogeneous nanochannels design, ion rectification can be enhanced by loading Au nanoparticles. Yang et al. [102] reported $\mathrm{TiO}_{2}$ nanochannel membranes loaded with spherical Au nanoparticles for near-infrared-gated artificial ionic nanochannels by a self-organizing anodization method. Owing to the limited light penetration depth, $\mathrm{Au}$ nanoparticles were deposited on the small tip side of the $\mathrm{TiO}_{2}$ nanochannel membranes. This asymmetric design showed obvious photothermal conversion. Through carbon coating, Wang et al. [103] fabricated a nanopore structure that realized high-efficiency ion accessibility and fast ion transmission. This $\mathrm{TiO}_{2}-\mathrm{C}$ hybrid nanopore structure was synthesized by electrospinning and calcination and used as the electrode. The electrode showed high ion accessibility. After about 100 cycles, its capacity increased slightly, completing the process of "self-improvement". 




(a)



(e)

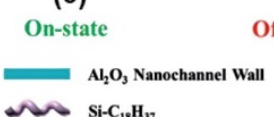

(d)

Off-state

$$
\sim \mathrm{Si}_{18} \mathrm{C}_{18} \mathrm{H}_{37}
$$



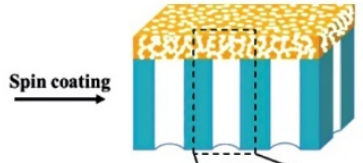

(b)

(

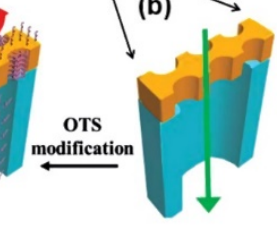

(c)

$\mathrm{TiO}_{2}$ Nanochannel Wall

e. $\mathrm{Si}_{\mathrm{n}} \mathrm{C}_{\mathrm{n}} \mathrm{H}_{2 \mathrm{~B}} \mathrm{COO}^{-}(\mathrm{n}=0-17)$

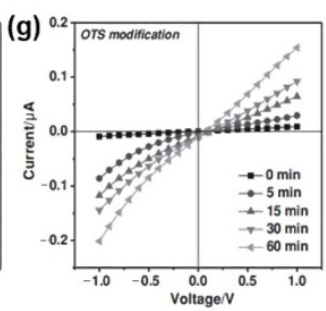

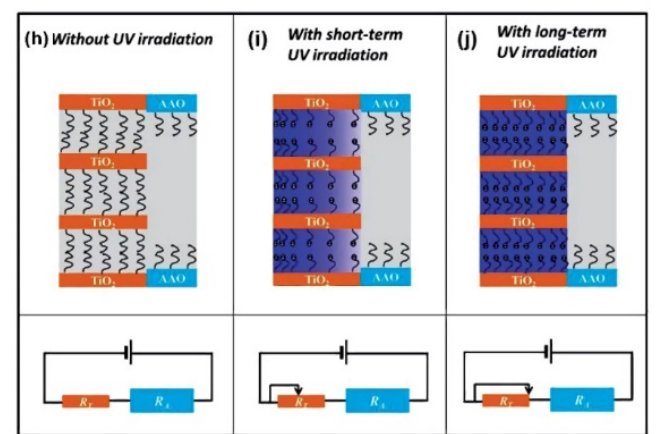

(k)



Figure 6. $\mathrm{TiO}_{2}-\mathrm{Al}_{2} \mathrm{O}_{3}$ heterogeneous nanochannels for ion rectification. (a) $\mathrm{Al}_{2} \mathrm{O}_{3}$ porous structure. (b) $\mathrm{TiO}_{2}$ porous coating deposited on $\mathrm{Al}_{2} \mathrm{O}_{3}$ porous structure. (c) Magnified $\mathrm{TiO}_{2}-\mathrm{Al}_{2} \mathrm{O}_{3}$ heterogeneous nanochannels. (d) Octadecyltrimethoxysilane (OTS) molecules were modified on the $\mathrm{TiO}_{2} / \mathrm{Al}_{2} \mathrm{O}_{3}$ nanochannels, which showed superhydrophobic properties. (e) After UV irradiation, part of the $\mathrm{TiO}_{2}$ nanochannels became hydrophilic. (f,g) Image of the I-V property of $\mathrm{TiO}_{2} / \mathrm{Al}_{2} \mathrm{O}_{3}$ nanochannels by OTS modified/unmodified UV irradiation on $\mathrm{TiO}_{2}$. Reprint from [37]. (h) Fewer decomposed organic anions formed and smaller ion currents appeared without UV irradiation. (i) Some decomposed organic anions formed and normal ion currents appeared with short-term UV irradiation. (j) More decomposed organic anions formed and larger ion currents sappeared with long-term UV irradiation. Copyright (2014), with permission from WILEY-VCH, Weinheim, Germany. (k) Schematic diagram of photoexcited electron transition. Reprint from [100]. Copyright (1995), with permission from American Chemical Society, Washington, DC, USA.

\section{Conclusions}

$\mathrm{TiO}_{2}$-derived materials with superwettability reveal a great deal of significant properties such as being amphoteric oxides. We described some of the major works, which include those on ultra-fast spreading, controllable wettability, interfacial photocatalysis, and nanochannels for ion rectification. As a material with superior performance in selfcleaning and photocatalysis, the $\mathrm{TiO}_{2}$-based material with its superwettability should be studied further, especially in terms of mechanisms for the ultra-fast spreading of $\mathrm{TiO}_{2}$, and more work should focus on the interfacial triphase reaction.

Nature is the inspiration source of biomimetic materials. Interfacial catalysis and interfacial reactions benefit from nature. On this basis, the research of multi-functional $\mathrm{TiO}_{2}$ materials is an inevitable trend. How to combine superwettability with other functions will be the emphasis of future work. In recent years, the environmental pollution and energy problems have become more serious. We believe that the study of $\mathrm{TiO}_{2}$ multi-functional materials will provide researchers with a favorable solution.

Author Contributions: Conceptualization, Y.T. and L.J.; investigation, X.L., Z.Z., Y.T. and J.Y.; writing-original draft preparation, X.L.; writing-review and editing, X.L., Z.Z., Y.T. and L.J.; supervision, L.J. All authors have read and agreed to the published version of the manuscript.

Funding: This research was supported by the National Research Fund for Fundamental Key Projects (2019YFA0708702), National Natural Science Foundation (21972154, 21988102, 22090052, 22002005), Frontier Science Key Projects of CAS (ZDBS-LY-SLH022), Beijing Municipal Science \& Technology 
Commission No. Z181100004418014 (No. Z181100004418013), and China Postdoctoral Science Foundation (2019M660397, 2019TQ0014).

Data Availability Statement: No new data were created or analyzed in this study. Data sharing is not applicable to this article.

Acknowledgments: This article is part of the special issue "Commemorative Issue in Honor of Professor Akira Fujishima".

Conflicts of Interest: The authors declare no conflict of interest.

\section{References}

1. Fujishima, A.; Zhang, X.; Tryk, D.A. $\mathrm{TiO}_{2}$ photocatalysis and related surface phenomena. Surf. Sci. Rep. 2008, 63, 515-582. [CrossRef]

2. Bittoun, E.; Marmur, A. The Role of Multiscale Roughness in the Lotus Effect: Is It Essential for Super-Hydrophobicity? Langmuir 2012, 28, 13933-13942. [CrossRef]

3. Liu, K.; Cao, M.; Fujishima, A.; Jiang, L. Bio-Inspired Titanium Dioxide Materials with Special Wettability and Their Applications. Chem. Rev. 2014, 114, 10044-10094. [CrossRef]

4. Boesel, L.F.; Greiner, C.; Arzt, E.; Del Campo, A. Gecko-Inspired Surfaces: A Path to Strong and Reversible Dry Adhesives. Adv. Mater. 2010, 22, 2125-2137. [CrossRef]

5. Zhang, P.; Lin, L.; Zang, D.; Guo, X.; Liu, M. Designing Bioinspired Anti-Biofouling Surfaces based on a Superwettability Strategy. Small 2016, 13, 9. [CrossRef] [PubMed]

6. Bixler, G.D.; Bhushan, B. Fluid drag reduction and efficient self-cleaning with rice leaf and butterfly wing bioinspired surfaces. Nanoscale 2013, 5, 7685-7710. [CrossRef]

7. Duncan, W.R.; Stier, W.M.; Prezhdo, O.V. AbInitioNonadiabatic Molecular Dynamics of the Ultrafast Electron Injection across the Alizarin- $\mathrm{TiO}_{2}$ Interface. J. Am. Chem. Soc. 2005, 127, 7941-7951. [CrossRef] [PubMed]

8. Fowkes, F.M. Attractive Forces at Interfaces. Ind. Eng. Chem. 1964, 56, 40-52. [CrossRef]

9. Owens, D.K.; Wendt, R.C. Estimation of the surface free energy of polymers. J. Appl. Polym. Sci. 1969, 13, 1741-1747. [CrossRef]

10. Fujishima, A.; Honda, K. Electrochemical Photolysis of Water at a Semiconductor Electrode. Nat. Cell Biol. 1972, 238, 37-38. [CrossRef] [PubMed]

11. Wang, R.; Hashimoto, K.; Fujishima, A.; Chikuni, M.; Kojima, E.; Kitamura, A.; Shimohigoshi, M.; Watanabe, T. Light-induced amphiphilic surfaces. Nat. Cell Biol. 1997, 388, 431-432. [CrossRef]

12. Wang, R.; Sakai, N.; Fujishima, A.; Watanabe, A.T.; Hashimoto, K. Studies of Surface Wettability Conversion on TiO2Single-Crystal Surfaces. J. Phys. Chem. B 1999, 103, 2188-2194. [CrossRef]

13. Liu, M.; Wang, S.; Jiang, L. Nature-inspired superwettability systems. Nat. Rev. Mater. 2017, 2, 17. [CrossRef]

14. Zhu, Z.; Yu, Z.; Yun, F.F.; Pan, D.; Tian, Y.; Jiang, L.; Wang, X. Crystal face dependent intrinsic wettability of metal oxide surfaces. Natl. Sci. Rev. 2021, 8, nwaa166. [CrossRef]

15. Zhu, Z.; Tian, Y.; Chen, Y.; Gu, Z.; Wang, S.; Jiang, L. Superamphiphilic Silicon Wafer Surfaces and Applications for Uniform Polymer Film Fabrication. Angew. Chem. Int. Ed. 2017, 56, 5720-5724. [CrossRef]

16. Liu, Y.; Li, Z.; Green, M.; Just, M.; Li, Y.Y.; Chen, X. Titanium dioxide nanomaterials for photocatalysis. J. Phys. D Appl. Phys. 2017, 50, 193003. [CrossRef]

17. Van Vuuren, D.S.; Engelbrecht, A.D.; Hadley, T.D. Opportunities in the electrowinning of molten titanium from titanium dioxide. JOM 2005, 57, 53-55. [CrossRef]

18. Yang, Z.D. Application of titanium dioxide nano-particles on textile modification. In Advances in Textile Engineering and Materials Iii, Pts 1 and 2; Zheng, L., Skuroda, S., Liu, H., Du, B., Wei, J., Zhao, Y., Eds.; Advanced Materials Research; Trans Tech Publications Ltd.: Stafa, Switzerland, 2013; Volume 821-822, pp. 901-905.

19. Chen, F.; Xu, Y. The application of titanium dioxide of environment-friendly building materials. In Advanced Building Materials and Sustainable Architecture, Pts 1-4; Shao, Y., Hao, S., Luo, Y., Xing, J., Liu, Z., Eds.; Applied Mechanics and Materials; Trans Tech Publications Ltd.: Stafa, Switzerland, 2012; Volume 174-177, pp. 767-770.

20. Bayan, E.M.; Lupeiko, T.G.; Pustovaya, L.E. Optimization of Synthesis of Nanosized Titanium Dioxide Powder Materials from Peroxo Titanium Complex. Russ. J. Phys. Chem. B 2019, 13, 383-388. [CrossRef]

21. Guan, K. Relationship between photocatalytic activity, hydrophilicity and self-cleaning effect of $\mathrm{TiO}_{2} / \mathrm{SiO}_{2}$ films. Surf. Coat. Technol. 2005, 191, 155-160. [CrossRef]

22. López, J.E.O.; Jacoby, W.A. Microfibrous mesh coated with titanium dioxide: A self-sterilizing, self-cleaning filter. J. Air Waste Manag. Assoc. 2002, 52, 1206-1213. [CrossRef]

23. Lu, A.-X.; Lin, N.; Li, X.; Tan, C.-Y. Self-cleaning glass coated with $\mathrm{Fe}^{3+}-\mathrm{TiO}_{2}$ thin film. J. Cent. South Univ. Technol. 2004, 11, 124-127. [CrossRef]

24. Ohko, Y.; Utsumi, Y.; Niwa, C.; Tatsuma, T.; Kobayakawa, K.; Satoh, Y.; Kubota, Y.; Fujishima, A. Self-sterilizing and self-cleaning of silicone catheters coated with $\mathrm{TiO}_{2}$ photocatalyst thin films: A preclinical work. J. Biomed. Mater. Res. 2001, 58, 97-101. [CrossRef] 
25. Wolfrum, E.J.; Huang, J.; Blake, D.M.; Maness, P.-C.; Huang, Z.; Fiest, J.; Jacoby, W.A. Photocatalytic Oxidation of Bacteria, Bacterial and Fungal Spores, and Model Biofilm Components to Carbon Dioxide on Titanium Dioxide-Coated Surfaces. Environ. Sci. Technol. 2002, 36, 3412-3419. [CrossRef] [PubMed]

26. Aizenberg, J.; Fratzl, P. Biological and Biomimetic Materials. Adv. Mater. 2009, 21, 387-388. [CrossRef]

27. Alves, P.; Cardoso, R.; Correia, T.R.; Antunes, B.P.; Correia, I.J.; Ferreira, P. Surface modification of polyurethane films by plasma and ultraviolet light to improve haemocompatibility for artificial heart valves. Colloids Surf. B Biointerfaces 2014, 113, 25-32. [CrossRef]

28. Anpo, M.; Dohshi, S.; Kitano, M.; Hu, Y.; Takeuchi, M.; Matsuoka, M. The preparation and characterization of highly efficient titanium oxide-based photofunctional materials. Annu. Rev. Mater. Res. 2005, 35, 1-27. [CrossRef]

29. Ao, C.; Lee, S.; Mak, C.; Chan, L. Photodegradation of volatile organic compounds (VOCs) and NO for indoor air purification using $\mathrm{TiO}_{2}$ : Promotion versus inhibition effect of NO. Appl. Catal. B Environ. 2003, 42, 119-129. [CrossRef]

30. Barthlott, W.; Neinhuis, C. Purity of the sacred lotus, or escape from contamination in biological surfaces. Planta 1997, 202, 1-8. [CrossRef]

31. Bartolo, D.; Bouamrirene, F.; Verneuil, É.; Buguin, A.; Silberzan, P.; Moulinet, S. Bouncing or sticky droplets: Impalement transitions on superhydrophobic micropatterned surfaces. EPL Europhys. Lett. 2006, 74, 299-305. [CrossRef]

32. Wen, Q.; Di, J.; Zhao, Y.; Wang, Y.; Jiang, L.; Yu, J. Flexible inorganic nanofibrous membranes with hierarchical porosity for efficient water purification. Chem. Sci. 2013, 4, 4378-4382. [CrossRef]

33. Kang, H.; Liu, Y.; Lai, H.; Yu, X.; Cheng, Z.; Jiang, L. Under-Oil Switchable Superhydrophobicity to Superhydrophilicity Transition on $\mathrm{TiO}_{2}$ Nanotube Arrays. ACS Nano 2018, 12, 1074-1082. [CrossRef] [PubMed]

34. Tian, D.; Chen, Q.; Nie, F.-Q.; Xu, J.; Song, Y.; Jiang, L. Patterned Wettability Transition by Photoelectric Cooperative and Anisotropic Wetting for Liquid Reprography. Adv. Mater. 2009, 21, 3744-3749. [CrossRef]

35. Hu, Z.; Zhang, X.; Liu, Z.; Huo, K.; Chu, P.K.; Zhai, J.; Jiang, L. Regulating Water Adhesion on Superhydrophobic TiO ${ }_{2} \mathrm{Nanotube}$ Arrays. Adv. Funct. Mater. 2014, 24, 6381-6388. [CrossRef]

36. Wang, D.; Chen, L.; Liu, J.; Guan, F.; Sun, R.; Jiang, L.; Feng, X. A Reliable Photoelectrochemical Bioassay System Based on Cathodic Reaction at a Solid-Liquid-Air Joint Interface. Adv. Funct. Mater. 2018, 28, 28. [CrossRef]

37. Zhang, Q.; Hu, Z.; Liu, Z.; Zhai, J.; Jiang, L. Light-Gating Titania/Alumina Heterogeneous Nanochannels with Regulatable Ion Rectification Characteristic. Adv. Funct. Mater. 2013, 24, 424-431. [CrossRef]

38. Yu, Z.; Yun, F.F.; Gong, Z.; Yao, Q.; Dou, S.; Liu, K.; Jiang, L.; Wang, X. A novel reusable superhydrophilic NiO/Ni mesh produced by a facile fabrication method for superior oil/water separation. J. Mater. Chem. A 2017, 5, 10821-10826. [CrossRef]

39. Kulkarni, M.; Mazare, A.; Gongadze, E.; Perutkova, Š.; Kralj-Iglič, V.; Milošev, I.; Schmuki, P.; Iglič, A.; Mozetič, M. Titanium nanostructures for biomedical applications. Nanotechnology 2015, 26, 062002. [CrossRef] [PubMed]

40. Yeon, J.; Yen, Y.-M.; Nakamoto, M.; Tanaka, T. Metal-Metal Joining Using Super-Spread Wetting into Interface Fine Mesh Structure. Mater. Trans. 2018, 59, 1811-1816. [CrossRef]

41. Koepke, J.; Berndt, J.; Feig, S.T.; Holtz, F. The formation of $\mathrm{SiO}_{2}$-rich melts within the deep oceanic crust by hydrous partial melting of gabbros. Contrib. Miner. Petrol. 2007, 153, 67-84. [CrossRef]

42. Page, K.; Wilson, M.; Parkin, I.P. Antimicrobial surfaces and their potential in reducing the role of the inanimate environment in the incidence of hospital-acquired infections. J. Mater. Chem. 2009, 19, 3819-3831. [CrossRef]

43. Wang, S.; Liu, K.; Yao, X.; Jiang, L. Bioinspired Surfaces with Superwettability: New Insight on Theory, Design, and Applications. Chem. Rev. 2015, 115, 8230-8293. [CrossRef]

44. Li, W.; Cao, C.-Y.; Chen, C.-Q.; Zhao, Y.; Song, W.-G.; Jiang, L. Fabrication of nanostructured metal nitrides with tailored composition and morphology. Chem. Commun. 2011, 47, 3619-3621. [CrossRef]

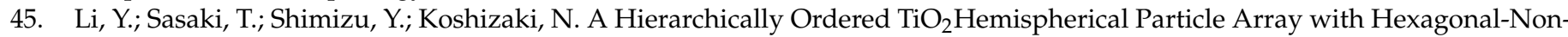
Close-Packed Tops: Synthesis and Stable Superhydrophilicity Without UV Irradiation. Small 2008, 4, 2286-2291. [CrossRef]

46. Zorba, V.; Chen, X.; Mao, S.S. Superhydrophilic $\mathrm{TiO}_{2}$ surface without photocatalytic activation. Appl. Phys. Lett. 2010, 96, 093702. [CrossRef]

47. Denison, K.R.; Boxall, C. Photoinduced “Stick-Slip" on Superhydrophilic Semiconductor Surfaces. Langmuir 2007, 23, 4358-4366. [CrossRef] [PubMed]

48. Ganesh, V.A.; Nair, A.S.; Raut, H.K.; Walsh, T.M.; Ramakrishna, S. Photocatalytic superhydrophilic $\mathrm{TiO}_{2}$ coating on glass by electrospinning. RSC Adv. 2012, 2, 2067-2072. [CrossRef]

49. Funakoshi, K.; Nonami, T. Preparation of a Superhydrophilic Thin Film on Glass Substrate Surfaces with Titanium Alkoxide Solution. J. Am. Ceram. Soc. 2006, 89, 2782-2786. [CrossRef]

50. Kobayashi, T.; Maeda, H.; Konishi, S. Photoresponsive wettability switching of $\mathrm{TiO}_{2}$-coated micropillar arrays with different geometries of overhang roofs. Micro Nano Lett. 2017, 12, 540-544. [CrossRef]

51. Joung, Y.S.; Buie, C.R. A Hybrid Method Employing Breakdown Anodization and Electrophoretic Deposition for Superhydrophilic Surfaces. J. Phys. Chem. B 2012, 117, 1714-1723. [CrossRef]

52. Wang, L.; Zhao, Y.; Wang, J.; Hong, X.; Zhai, J.; Jiang, L.; Wang, F. Ultra-fast spreading on superhydrophilic fibrous mesh with nanochannels. Appl. Surf. Sci. 2009, 255, 4944-4949. [CrossRef]

53. Chen, H.; Zhao, Y.; Song, Y.; Jiang, L. One-Step Multicomponent Encapsulation by Compound-Fluidic Electrospray. J. Am. Chem. Soc. 2008, 130, 7800-7801. [CrossRef] 
54. Chen, H.; Wang, N.; Di, J.; Zhao, Y.; Song, Y.; Jiang, L. Nanowire-in-Microtube Structured Core/Shell Fibers via Multifluidic Coaxial Electrospinning. Langmuir 2010, 26, 11291-11296. [CrossRef]

55. Chen, H.; Di, J.; Wang, N.; Dong, H.; Wu, J.; Zhao, Y.; Yu, J.; Jiang, L. Fabrication of Hierarchically Porous Inorganic Nanofibers by a General Microemulsion Electrospinning Approach. Small 2011, 7, 1779-1783. [CrossRef]

56. Yang, X.; Huang, Y.; Zhao, Y.; Zhang, X.; Wang, J.; Sann, E.E.; Mon, K.H.; Lou, X.; Xia, F. Bioinspired Slippery Lubricant-Infused Surfaces With External Stimuli Responsive Wettability: A Mini Review. Front. Chem. 2019, 7, 7. [CrossRef]

57. Zheng, S.; Wang, D.; Tian, Y.; Jiang, L. Superhydrophilic Coating Induced Temporary Conductivity for Low-Cost Coating and Patterning of Insulating Surfaces. Adv. Funct. Mater. 2016, 26, 9018-9025. [CrossRef]

58. Linlin, H.; He, L.; Zhang, X.; Zhang, N.; Tian, D. External-Field-Induced Gradient Wetting for Controllable Liquid Transport: From Movement on the Surface to Penetration into the Surface. Adv. Mater. 2017, 29, 29. [CrossRef]

59. Guo, F.; Guo, Z. Inspired smart materials with external stimuli responsive wettability: A review. RSC Adv. 2016, 6, 36623-36641. [CrossRef]

60. Lai, Y.; Huang, J.; Cui, Z.; Ge, M.; Zhang, K.-Q.; Chen, Z.; Chi, L. Recent Advances in $\mathrm{TiO}_{2}$-Based Nanostructured Surfaces with Controllable Wettability and Adhesion. Small 2016, 12, 2203-2224. [CrossRef] [PubMed]

61. Zeng, P.; Liu, Z.; Hu, Z.; Zhai, J.; Jiang, L. TiO2 nanotubular arrays loaded with $\mathrm{Ni}(\mathrm{OH})_{2}$ : Naked-eye visible photoswitchable color change induced by oxidative energy storage. RSC Adv. 2013, 3, 22853. [CrossRef]

62. Gao, H.; Liu, Y.; Wang, G.Y.; Li, S.; Han, Z.; Ren, L. Switchable Wettability Surface with Chemical Stability and Antifouling Properties for Controllable Oil-Water Separation. Langmuir 2019, 35, 4498-4508. [CrossRef]

63. Chagas, G.R.; Weibel, D.E. UV-induced switchable wettability between superhydrophobic and superhydrophilic polypropylene surfaces with an improvement of adhesion properties. Polym. Bull. 2016, 74, 1965-1978. [CrossRef]

64. Caputo, G.; Cingolani, R.; Cozzoli, P.D.; Athanassiou, A. Wettability conversion of colloidal $\mathrm{TiO}_{2}$ nanocrystal thin films with UV-switchable hydrophilicity. Phys. Chem. Chem. Phys. 2009, 11, 3692-3700. [CrossRef] [PubMed]

65. Wang, D.; Liu, Y.; Liu, X.; Zhou, F.; Liu, W.; Xue, Q. Towards a tunable and switchable water adhesion on a $\mathrm{TiO}_{2}$ nanotube film with patterned wettability. Chem. Commun. 2009, 10, 7018-7020. [CrossRef] [PubMed]

66. Feng, X.; Zhai, J.; Jiang, L. The Fabrication and Switchable Superhydrophobicity of $\mathrm{TiO}_{2}$ Nanorod Films. Angew. Chem. Int. Ed. 2005, 44, 5115-5118. [CrossRef]

67. Lian, Z.; Xu, J.; Wang, Z.; Weng, Z.; Xu, Z.; Yu, H. Reversibly switchable wettability between underwater superoleophobicity and oleophobicity of titanium surface via ethanol immersion and dark storage. Appl. Surf. Sci. 2016, 390, 244-247. [CrossRef]

68. Lai, Y.K.; Gao, X.F.; Zhuang, H.F.; Huang, J.Y.; Lin, C.J.; Jiang, L. Designing superhydrophobic porous nanostructures with tunable water adhesion. Adv. Mater. 2009, 21, 3799-3803. [CrossRef]

69. Li, Y.; Li, J.; Liu, L.; Yan, Y.; Zhang, Q.; Zhang, N.; He, L.; Liu, Y.; Zhang, X.; Tian, D.; et al. Switchable wettability and adhesion of micro/nanostructured elastomer surface via electric field for dynamic liquid droplet manipulation. Adv. Sci. 2020, 7, 2000772. [CrossRef] [PubMed]

70. Liu, W.; Cai, J.; Ding, Z.; Li, Z. $\mathrm{TiO}_{2} /$ RGO composite aerogels with controllable and continuously tunable surface wettability for varied aqueous photocatalysis. Appl. Catal. B Environ. 2015, 174-175, 421-426. [CrossRef]

71. Pan, Y.; Kong, W.; Bhushan, B.; Zhao, X. Rapid, ultraviolet-induced, reversibly switchable wettability of superhydrophobic/superhydrophilic surfaces. Beilstein J. Nanotechnol. 2019, 10, 866-873. [CrossRef]

72. Shi, B.; Jia, X.; Guo, Z. An easy preparation of photo-response $\mathrm{TiO}_{2} @$ copper wire mesh with quick on/off switchable superwetting for high efficiency oil-water separation. New J. Chem. 2018, 42, 17563-17573. [CrossRef]

73. Yan, L.; Liu, C.; Xia, J.; Chao, M.; Wang, W.; Gu, J.; Chen, T. CNTs/ TiO 2 composite membrane with adaptable wettability for on-demand oil/water separation. J. Clean. Prod. 2020, 275, 124011. [CrossRef]

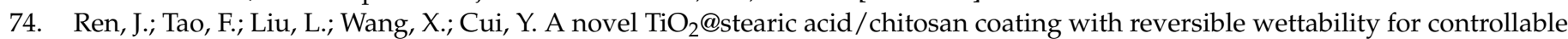
oil/water and emulsions separation. Carbohydr. Polym. 2020, 232, 115807. [CrossRef] [PubMed]

75. Guo, Z.; Zhang, X.; Zheng, X.; Liu, Z.; Cai, J.; Tian, D.; Li, W.; Zhai, J.; Song, Y.; Jiang, L. Patterned liquid permeation through the $\mathrm{TiO}_{2}$ nanotube array coated Ti mesh by photoelectric cooperation for liquid printing. J. Mater. Chem. A 2014, 2, 2498. [CrossRef]

76. Guo, Z.; Zheng, X.; Tian, D.; Song, Y.; Zhai, J.; Zhang, X.; Li, W.; Wang, X.; Dou, S.; Jiang, L. Photoelectric cooperative patterning of liquid permeation on the micro/nano hierarchically structured mesh film with low adhesion. Nanoscale 2014, 6, 12822-12827. [CrossRef] [PubMed]

77. Deng, X.; Mammen, L.; Butt, H.-J.; Vollmer, D. Candle soot as a template for a transparent robust superamphiphobic coating. Science 2012, 335, 67-70. [CrossRef] [PubMed]

78. Heller, A.; Feldman, B. Electrochemical glucose sensors and their applications in diabetes management. Chem. Rev. 2008, 108, 2482-2505. [CrossRef] [PubMed]

79. Niu, F.; Zhang, L.-S.; Chen, C.-Q.; Li, W.; Li, L.; Song, W.-G.; Jiang, L. Hydrophilic $\mathrm{TiO}_{2}$ porous spheres anchored on hydrophobic polypropylene membrane for wettability induced high photodegrading activities. Nanoscale 2010, 2, 1480-1484. [CrossRef]

80. Tao, J.; Sun, Z.; Cheng, Y.; Zhang, M.; Lv, J.; Shi, S.; He, G.; Jiang, X.; Chen, X.; Wang, X.; et al. Enhanced photoelectrochemical properties of nanocrystalline $\mathrm{TiO}_{2}$ electrode by surface sensitization with CuxO quantum dots. Sci. Rep. 2017, 7, 5291. [CrossRef]

81. Lee, H.; Choi, T.K.; Lee, Y.B.; Cho, H.R.; Ghaffari, R.; Wang, L.; Choi, H.J.; Chung, T.D.; Lu, N.; Hyeon, T.; et al. A graphene-based electrochemical device with thermoresponsive microneedles for diabetes monitoring and therapy. Nat. Nanotechnol. 2016, 11, 566-572. [CrossRef] [PubMed] 
82. Feng, L.; Li, S.; Li, Y.; Li, H.; Zhang, L.; Zhai, J.; Song, Y.; Liu, B.; Jiang, L.; Zhu, D. Super-hydrophobic surfaces: From natural to artificial. Adv. Mater. 2002, 14, 1857-1860. [CrossRef]

83. Lafuma, A.; Quéré, D. Superhydrophobic states. Nat. Mater. 2003, 2, 457-460. [CrossRef] [PubMed]

84. Chen, L.; Sheng, X.; Wang, D.; Liu, J.; Sun, R.; Jiang, L.; Feng, X. High-performance triphase bio-photoelectrochemical assay system based on superhydrophobic substrate-supported $\mathrm{TiO}_{2}$ Nanowire Arrays. Adv. Funct. Mater. 2018, 28, 28. [CrossRef]

85. Zhang, T.; Lin, P.; Wei, N.; Wang, D. Enhanced photoelectrochemical water-splitting property on TiO $\mathrm{O}_{2}$ nanotubes by surface chemical modification and wettability control. ACS Appl. Mater. Interfaces 2020, 12, 20110-20118. [CrossRef]

86. Rafieerad, A.; Bushroa, A.; Nasiri-Tabrizi, B.; Vadivelu, J.; Yusof, F.; Baradaran, S. Graphene Oxide Modified Anodic Ternary Nanobioceramics on Ti6Al7Nb alloy for orthopedic and dental applications. Procedia Eng. 2017, 184, 409-417. [CrossRef]

87. Zhu, Z.; Wang, D.; Tian, Y.; Jiang, L. Ion/Molecule transportation in nanopores and nanochannels: From critical principles to diverse functions. J. Am. Chem. Soc. 2019, 141, 8658-8669. [CrossRef]

88. Fu, L.; Zhai, J. Biomimetic stimuli-responsive nanochannels and their applications. Electrophoresis 2019, 40, 2058-2074. [CrossRef]

89. Ding, D.; Gao, P.; Ma, Q.; Wang, D.; Xia, F. Biomolecule-functionalized solid-state ion nanochannels/nanopores: Features and techniques. Small 2019, 15, e1804878. [CrossRef]

90. Xiao, K.; Kong, X.-Y.; Zhang, Z.; Xie, G.; Wen, L.; Jiang, L. Construction and application of photoresponsive smart nanochannels. J. Photochem. Photobiol. C Photochem. Rev. 2016, 26, 31-47. [CrossRef]

91. Wen, L.; Zhang, X.; Tian, Y.; Jiang, L. Quantum-confined superfluid: From nature to artificial. Sci. China Mater. 2018, 61, 1027-1032. [CrossRef]

92. Wen, L.; Jiang, L. Construction of biomimetic smart nanochannels for confined water. Natl. Sci. Rev. 2014, 1, 144-156. [CrossRef]

93. Meng, X.; Huang, J. Control water molecules across carbon-based nanochannels. Chin. Phys. B 2018, 27, 13101. [CrossRef]

94. Xia, D.; Yan, J.; Hou, S. Fabrication of nanofluidic biochips with nanochannels for applications in DNA analysis. Small 2012, 8 , 2787-2801. [CrossRef] [PubMed]

95. Hao, Z.; Zhang, Q.; Xu, X.; Zhao, Q.; Wu, C.; Liu, J.; Wang, H. Nanochannels regulating ionic transport for boosting electrochemical energy storage and conversion: A review. Nanoscale 2020, 12, 15923-15943. [CrossRef] [PubMed]

96. Li, R.; Fan, X.; Liu, Z.; Zhai, J. Smart bioinspired nanochannels and their applications in energy-conversion systems. Adv. Mater. 2017, 29, 29. [CrossRef]

97. Zhang, X.; Liu, H.; Jiang, L. Wettability and applications of nanochannels. Adv. Mater. 2019, 31, e1804508. [CrossRef]

98. Zhang, Q.; Liu, Z.; Hou, X.; Fan, X.; Zhai, J.; Jiang, L. Light-regulated ion transport through artificial ion channels based on TiO 2 nanotubular arrays. Chem. Commun. 2012, 48, 5901-5903. [CrossRef]

99. Liu, G.-C.; Song, L.-B.; Gao, M.-J.; Wang, X.-H.; Li, C.-Q.; Liu, B.; Zhao, Y.-D.; Chen, W. Ion current rectification in high-salt environment from mesoporous $\mathrm{TiO}_{2}$ microplug in situ grown at the tip of a micropipette induced by space-confined evaporation. Anal. Chem. 2019, 91, 15377-15381. [CrossRef]

100. Linsebigler, A.L.; Lu, G.; Yates, J.T. Photocatalysis on $\mathrm{TiO}_{2}$ surfaces: Principles, mechanisms, and selected results. Chem. Rev. 1995, 95, 735-758. [CrossRef]

101. Hu, Z.; Zhang, Q.; Gao, J.; Liu, Z.; Zhai, J.; Jiang, L. Photocatalysis-triggered ion rectification in artificial nanochannels based on chemically modified asymmetric $\mathrm{TiO}_{2}$ nanotubes. Langmuir 2013, 29, 4806-4812. [CrossRef]

102. Yang, L.; Qu, K.; Guo, J.; Xu, H.; Dai, Z.; Gao, Z.-D.; Song, Y.-Y. Asymmetric coupling of Au nanospheres on $\mathrm{TiO}_{2}$ nanochannel membranes for NIR-gated artificial ionic nanochannels. Chem. Commun. 2019, 55, 14625-14628. [CrossRef]

103. Wang, N.; Gao, Y.; Wang, Y.; Liu, K.; Lai, W.; Hu, Y.; Zhao, Y.; Chou, S.; Jiang, L. Nanoengineering to achieve high sodium storage: A case study of carbon coated hierarchical nanoporous $\mathrm{TiO}_{2}$ microfibers. Adv. Sci. 2016, 3, 1600013. [CrossRef] [PubMed] 